\title{
ANYAGTUDOMÁNY LABORGYAKORLAT MÓDSZERTANI FEJLESZTÉSE
}

\section{METHODOLOGY DEVELOPMENT OF MATERIALS SCIENCE PRACTICE}

\author{
Kuti János \\ Óbudai Egyetem, Cím: 1034, Magyarország, Budapest Bécsi út 96/b, Telefon / Fax: \\ +3616665715,kuti.janos@bgk.uni-obuda.hu
}

\begin{abstract}
The innovation of the education methodology is important on base on the student feedback, because the student number is rising in the Hungarian higher education. I show my research results on base of 7 years works in material science subject what I built in the Óbuda University Faculty of Bánki Donát Mechanical and Safety Engineering. It can declare on base of the experiences that this innovation of the education gives results.
\end{abstract}

Keywords: methodology, open laboratory, materials science.

\section{Összefoglalás}

A mai magyar felsőoktatásban a tömegesedés miatt egyre fontosabb, hogy újabb módszerekkel a hallgatói visszajelzései alapján alakítsuk át az oktatást. A cikkemben egy 7 éves folyamat eredményeit mutatom be, mellyel az Óbudai Egyetem Bánki Donát Gépész és Biztonságtechnikai Mérnöki Karán egy oktatási rendszert építettünk fel az anyagtudomány tárgy oktatására. A tapasztalatok alapján kijelenthető, hogy az oktatás fejlesztése eredményeket hozott.

Kulcsszavak: módszertan, nyitott labor, anyagtudomány.

\section{Kiinduló helyzet}

Egy olyan oktatási rendszerben oktatunk, ahol a gyakorlatokon meghatározott témaköröket a gyakorlati oktató egy rövid előadásban bemutatta, majd az elmélet után a gyakorlatban is megvalósítottuk a méréseket. Ezt a rendszert összehasonlítottuk egy középiskolai oktatási rendszerrel. A fő különbségek:

Felsőoktatás:

- óraszám kettő elmélet + kettő gyakorlat hetente;

- számonkérés időszakos ( $\mathrm{kb}$ hat hetente zárthelyi dolgozatban);

Középoktatás:
- hat - nyolc óra hetente szakirányos tantárgyból;

- számonkérés hetente (felelet lehetősége, vagy röpdolgozat lehetösége);

Ha tantárgytól eltekintve nézzük meg a középoktatást és a felsőoktatást oktatás módszertanilag, akkor is feltünik néhány dolog.

A középiskolában a diáknak folyamatosan kell tanulnia, fontos, hogy kell, mert bármelyik órán számon kérhetik. A Középoktatásban a diáknak hat olyan tantárgya van, ami tényleges tanulmányokkal jár (osztályfőnöki óra, testnevelés, ének nem számítva), míg a felsőoktatás mintatanterveit megnézve hét -kilenc tantárgyat kell tanul- 
niuk. Tehát összegezve a felsőoktatásban több tárgyat, kevesebb óraszámban kell elsajátítani, azaz több az elvárt önálló munka a frissen belépő hallgatótól. Ezt nehezíti az, hogy míg a közoktatásban a heti tanulásra kényszerítettük a diákokat (számonkérés lehetőségének fenyegetése) addig a felsőoktatásban csak hat hetente kértünk számon, sok esetben nagyobb anyagmennyiségböl, mint az érettségi vizsga volt.

\section{Oktatási rendszerünk}

A fentebb leírtak alapján tehát szerettünk volna egy olyan oktatási közeget létrehozni, ahol folyamatos számonkérés van, ahol az önálló munka nem az otthon eltöltött időben történik, hanem a gyakorlaton. Nyilván nem egy teljesen új rendszert szerettünk volna létrehozni, hanem egy müködőt a saját képünkre formálni. Erre optimálisnak a nyitott labor rendszere tünt.

\subsection{Ideális rendszer}

Egy olyan képzésen, ahol zömében gyártástervező illetve géptervező konstruktor gépészmérnököket képzünk, ott arra törekednénk, hogy minél magasabb óraszám legyen a gyakorlati képzés, minél több gyakorlati kompetenciát sajátítsanak el a hallgatók. Így az ideális az lenne, ha minden hallgató saját maga megtervezné a szabványok szerint a próbatesteket, majd ezt a gépmühely gyakorlatuk során le is gyártanák. Ezek után a saját próbatesten végeznék el méréseket és a kiértékeléseket.

A munka mennyiségből látszik, hogy ez ténylegesen egy idea a nagy létszámú képzéseknél sajnos nem kivitelezhető.

\subsection{Nyitott labor}

A nyitott labor az oktatásban egy olyan oktatási hely, ahol a több egyforma mérö hely van. A hallgatóknak a mérésekre elkészített segédletekböl, illetve egyéb anyagokból önállóan kell felkészülni. Az óra elején egy rövid teszt után felügyelet mellett önállóan végre hajtani a feladatokat egy mérési utasításból. Ezzel a rendszerrel az volt a fö gondunk, hogy túl nagy beruházásokat igényelt volna hiszen egy háromszázhúsz fös évfolyamnál tizennégy hetes szemeszterrel számolva huszonhárom mérési helyet kellet volna biztosítani egy mérésböl egy napra. Ehhez legalább öt mérő állomás kellene. Az Óbudai Egyetemen ez több gépből két - három új beszerzését jelentette volna. A másik nagy beruházási tétel, hogy mindenkinek legyen próbatestje, sajnos háromszázhúsz főnél ez is nagy kiadás.

\subsection{A megvalósított rendszer}

Mivel a nyitott labor megvalósítása a beruházások miatt nem lehetséges, ezért egy általunk félig nyitott labor rendszer alakítottunk ki.

Minden órán beugró zárthelyi írása kötelező vagy a kollegák szóbeli számonkérést végeznek, ehhez minden laborméréshez készítettünk egy hét - huszonegy oldalas jegyzetet húsz - huszonöt ellenőrző kérdéssel. Gyakorlatok tíz - tizenöt fös csoportokban történek kilencven perces foglalkozásokon. Így a beugró számonkérése maximum tizenöt percet vesz igénybe. Ezek után a méréseket az oktató vezetésével elvégzik a hallgatók, elméleti kiegészítésekkel. Az ez előtti rendszerben ugye kis előadást tartott az oktató, így kevesebb idő jutott a gyakorlat bemutatására és átbeszélésére. Jelen esetben a bemutatáson és a gépmüködésen az anyagviselkedések átbeszélésére kerül a hangsúly. Több próbadarabon tudjuk elvégezni a mérést, így nagyobb esélylyel tudnak megfelelő következtetéseket levonni a hallgatók saját tapasztalatok alapján, jobban megértik az anyag részt.

A két táblázatból jól láthatóak a létszám adatok. Az 1. táblázatban láthatjuk az érdemjegyek közti eloszlást. Ebből egyrészt megállapítható, hogy a rendszerben egyik következménye a letiltás. Ez abból adódik, hogy szabályozások értelmében $30 \%$ a megengedett mulasztás, viszont ezt szabályoztuk, hiányzás: 
- ha nem jelenik meg órán;

- ha nem teljesíti a beugrót;

- ha nem teljesíti a jegyzökönyvet;

1. táblázat Anyagtudomány I. létszámadatai

\begin{tabular}{|r|c|c|c|c|r|r|r|r|}
\hline & 2007 & 2008 & 2009 & 2010 & 2011 & 2012 & 2013 & 2014 \\
\hline 1 & $\mathbf{3 0 7}$ & $\mathbf{1 2 6}$ & $\mathbf{1 4 0}$ & $\mathbf{1 1 5}$ & 121 & 169 & 118 & 204 \\
\hline 2 & $\mathbf{6 7}$ & $\mathbf{7 5}$ & $\mathbf{5 5}$ & $\mathbf{9 5}$ & 106 & 39 & 54 & 41 \\
\hline 3 & $\mathbf{3 6}$ & $\mathbf{7 5}$ & $\mathbf{6 3}$ & $\mathbf{5 9}$ & 45 & 42 & 60 & 25 \\
\hline 4 & $\mathbf{1}$ & $\mathbf{1 0}$ & $\mathbf{2 0}$ & $\mathbf{8}$ & 1 & 5 & 7 & 9 \\
\hline 5 & $\mathbf{0}$ & $\mathbf{0}$ & $\mathbf{1}$ & $\mathbf{0}$ & 0 & 0 & 0 & 1 \\
\hline letiltva & - & $\mathbf{1 5 1}$ & $\mathbf{5 3}$ & $\mathbf{9 1}$ & $\mathbf{7 6}$ & 130 & 97 & 90 \\
\hline Összesen & 411 & $\mathbf{4 3 7}$ & 332 & 368 & 349 & $\mathbf{3 8 5}$ & $\mathbf{3 3 6}$ & $\mathbf{3 7 0}$ \\
\hline
\end{tabular}

2. táblázat Eredményeség Anyagtudományból

\begin{tabular}{|l|r|r|r|r|r|r|r|r|}
\cline { 2 - 9 } \multicolumn{1}{c|}{} & 2007 & 2008 & 2009 & 2010 & 2011 & 2012 & 2013 & 2014 \\
\hline Eredménytelen & 307 & 277 & 193 & 206 & 197 & 299 & 215 & 294 \\
\hline Eredményes & 104 & 160 & 139 & 162 & 152 & 86 & 121 & 76 \\
\hline $\begin{array}{l}\text { Eredményes/ } \\
\text { eredménytelen }\end{array}$ & 0,34 & 0,58 & 0,72 & 0,79 & 0,77 & 0,29 & 0,56 & 0,26 \\
\hline
\end{tabular}

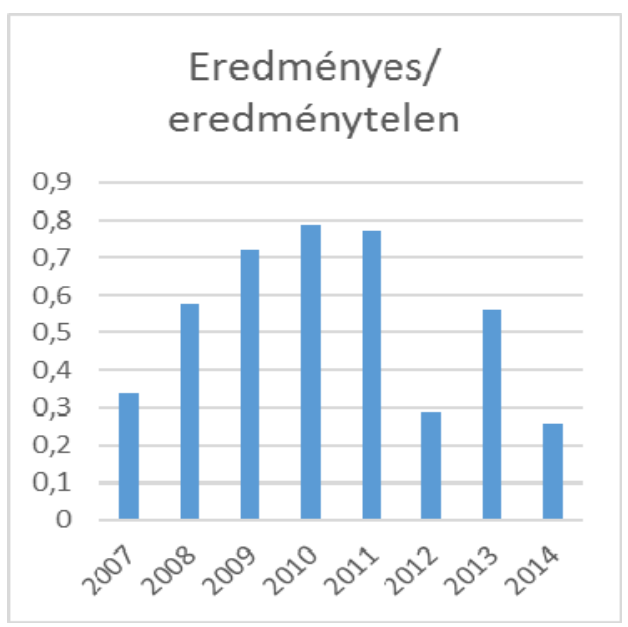

1. ábra Eredményeségi mutató

A beugró miatt a hiányzások száma megnövekedett, most már szellemileg is jelen kell lenni, nem elég testileg.

A 2. táblázat alapján látható, hogy 2012-ig az eredményes/ eredménytelen arány növekszik, azaz \%-osan több hallgató teljesítette a tárgyat (1. ábra).

A romlás több okból tevődik össze.

Az egyik ok a hallgató. A hallgató legföbb tulajdonsága, hogy a kisebb ellenállás felé áramlik. Így az elején kiadott jegyzeteket az első két évfolyam még átolvasta, kijegyzetelte, a harmadik évfolyamtól kezdve pedig már csak az elöző két évfolyam jegyzeteit olvasták, így sokkal roszszabb lett az elsajátítás szintje. Tehát a hallgató már nem az anyagot szerette volna megtanulni, hanem csak a beugrót túlélni, ehhez kell kisebb energia.

Másik ok az oktató. Az oktatói attitüd változása kimutatható az eredményeség mentén. Amíg a Kollegák következetesen szigorúan követelték meg a beugrókat, addig sokkal nagyobb volt a tanulási kényszer a hallgató felett. Ezen fegyelem fellazulása 2012 -re ért el csúcsot, amikor több új gyakorlatvezető kollegát rosszul vezettünk be az oktatásba. Továbbá néhány kollegánál a terhelés megnövekedésével nem volt annyi energia, hogy a beugrók és jegyzőkönyvek javítása folyamatos és naprakész legyen. Így pedig nem volt korrekt a visszajelzés a hallgatóknak a heti teljesítményről, kisebb lett a tanulási motiváció.

\section{Következtetések}

A rendszer felépítésénél elég sok kényszer volt számunkra, ezek leginkább anyagi jellegüek voltak, illetve az épületünk korlátai. Nincsenek szabad helyeink az épületünkben egy-egy nyitott laboratórium létrehozásához, bevezetéséhez. Ebből kifolyólag az egyik következtetés, hogy erre a célra több pénz kell az oktatásban!

A hallgatókon kicsit nehezebb változtatni, az oktatók hozzáállásán azonban viszonylag könnyebb. Tehát a félév eleji értekezleten meg kell határozni a beugrókat, a javításokat, tisztázni kell mindenki számára a szabályokat. 
További következtetés, hogy a számonkérésekből ki kell zárni az oktató személyes jelenlétét. Ez ma már több formában megoldható. Mi a tesztes számonkérés felé fejlesztünk. Több rendszer van, ami alkalmas arra, hogy meghatározott kérdés számot a kérdéseket rotálva, a kérdésre választható megoldásoka sorrendjét is forgatva kérdezzen, a kérdésekre meghatározott időtartam alatt válaszolni kell a hallgatónak. Így kizárható az oktató attitüd és azonnal emailben megkaphatja a választ a hallgató. A fejlesztésünk afelé halad, hogy gyakorlatonként legyen 50-60 tesztkérdés, melynek a fele mindig elérhető gyakorlási céllal, míg a kérdések másik felét csak a számonkéréskor használjuk a fentebb leírt rotációkkal.

\section{Szakirodalmi hivatkozások}

[1] A szaktanár oktató-nevelö munkájának fejlesztése elökészitő és tervezö-szervezö tevékenységgel (Mérnöktanári szakdolgozat), BME Tanárképző és Pszichológiai Intézet, 1989, 86 oldal

[2] Bagyinszki Gyula: Szakmódszertan III. (Anyag- és gyártásismeret) - oktatási segédlet, 44 oldal

[3] Bagyinszki Gyula, Bitay Enikő: Anyagtudományi gyakorlat-modulok a gépész- és mechatronikai mérnök képzésben, XVI. Fiatal Müszakiak Tudományos Ülésszaka, Kolozsvár, 2011. március 24-25.; Müszaki Tudományos Füzetek - Erdélyi Múzeum-Egyesület kiadványa (ISSN 2067 6 808) 5-16. o.

[4] Bitay Enikő, Bagyinszki Gyula: A müszaki anyagtudomány gyakorlatorientált oktatási struktúrája, XVI. Fiatal Müszakiak Tudományos Ülésszaka, Kolozsvár, 2011. március 24-25.; Müszaki Tudományos Füzetek - Erdélyi Múzeum-Egyesület kiadványa (ISSN 2067 - 6 808) 47-58. o.

[5] Bitay Enikő, Bagyinszki Gyula: Anyagszerkezettani vizsgálatok a müszaki anyagtudomány oktatásában, XVII. Fiatal Müszakiak Tudományos Ülésszaka, Kolozsvár, 2012. március 22-23.; Müszaki Tudományos Füzetek - Erdélyi MúzeumEgyesület kiadványa (ISSN 2067 - 6 808) 51-54. o.

[6] Bitay Enikő, Bagyinszki Gyula: Hegesztörobotokra vonatkozó ismeretek oktatásának módszertani szempontjai, XIX. Fiatal Müszakiak Tudományos Ülésszaka, Kolozsvár, 2014. március 20-21.; Müszaki Tudományos Közlemények 3. - Erdélyi Múzeum-Egyesület kiadványa (ISSN 2067 6 808) 73-76. o. 